\title{
EFISIENSI YANG TINGGI MERUPAKAN SYARAT UTAMA MEMENANGKAN PERSAINGAN PADA PERUSAHAAN MANUFAKTUR SEKTOR ANEKA INDUSTRI
}

\author{
R Gatot Heru Pranjoto \\ Universitas Trunojoyo Madura
}

\begin{abstract}
Competition is won by the company with high efficiency, which in its operation has high operating leverage, it means the increase of operating profit followed by higher output increase, hence the increase of fixed cost, can decrease higher variable cost. High degree of operating can be obtained through several factors, among others through cost efficiency, partnerships with customers and continuous improvement
\end{abstract}

Keyword : Operating leverage, Financial Leverage

\section{PENDAHULUAN}

Di era perkembangan teknologi keuangan yang sangat pesat, Perencanaan laba merupakan syarat utama bagi perusahaan, dimana dengan perencanaan laba dapat diketahui pada tingkat penjualan tertentu perusahaan akan berada pada suatu titik yang dinamakan break event point, suatu titik dimana perusahaan dalam posisi keseimbangan yaitu tidak mendapatkan laba juga tidak menderita kerugian.

Margin of safety, merupakan konsep seberapa besar tingkat keuntungan yang diharapkan perusahaan, agar tetap lancar dalam operasionalnya, kelancaran operasional perusahaan akan sangat berarti jika perusahaan dapat menerapkan teknik pemanufakturan yang tepat, serta memperoleh efisiensi yang tinggi. Dengan efisiensi yang tinggi perusahaan akan mampu bersaing dan memenangkan persaingan baik didalam industri maupun antar industri.

\section{TINJAUAN PUSTAKA}

\section{Perencanaan dan Pengendalian Laba}

Selain analisa rasio, Manajer Keuangan mempunyai alat lain untuk membantu dalam perencanakan dan pengendalian laba, yaitu Analisa Impas, analisa operating leverage dan analisa sumber dan penggunaan dana.

1. Analisa impas memberikan informasi pada volume penjualan berapakah total penghasilan dapat menutup total biaya secara penuh. 
2. Analisa impas memberkan informasi tentang perbandingan harga, volume yang diharapkan dan volume yang diharapkan untuk menutup biaya.

3. Untuk menilai program modernisasi atau otomatisasi menyerap biaya tetap (operating leverage) yang menguntungkan atau tidak.

4. Untuk melihat pengaruh ekspansi umum terhadap tingkat operasi, dimana titik impas dihitung atas dasar total penjualan (dalam rupiah bukan output) dan total biaya.

5. Dalam rangka pengambilan keputusa produk baru, analisa impas akan menunjukkan berapa besar produk baru harus dibuat agar keuntungan yang diharapkan tercapai.

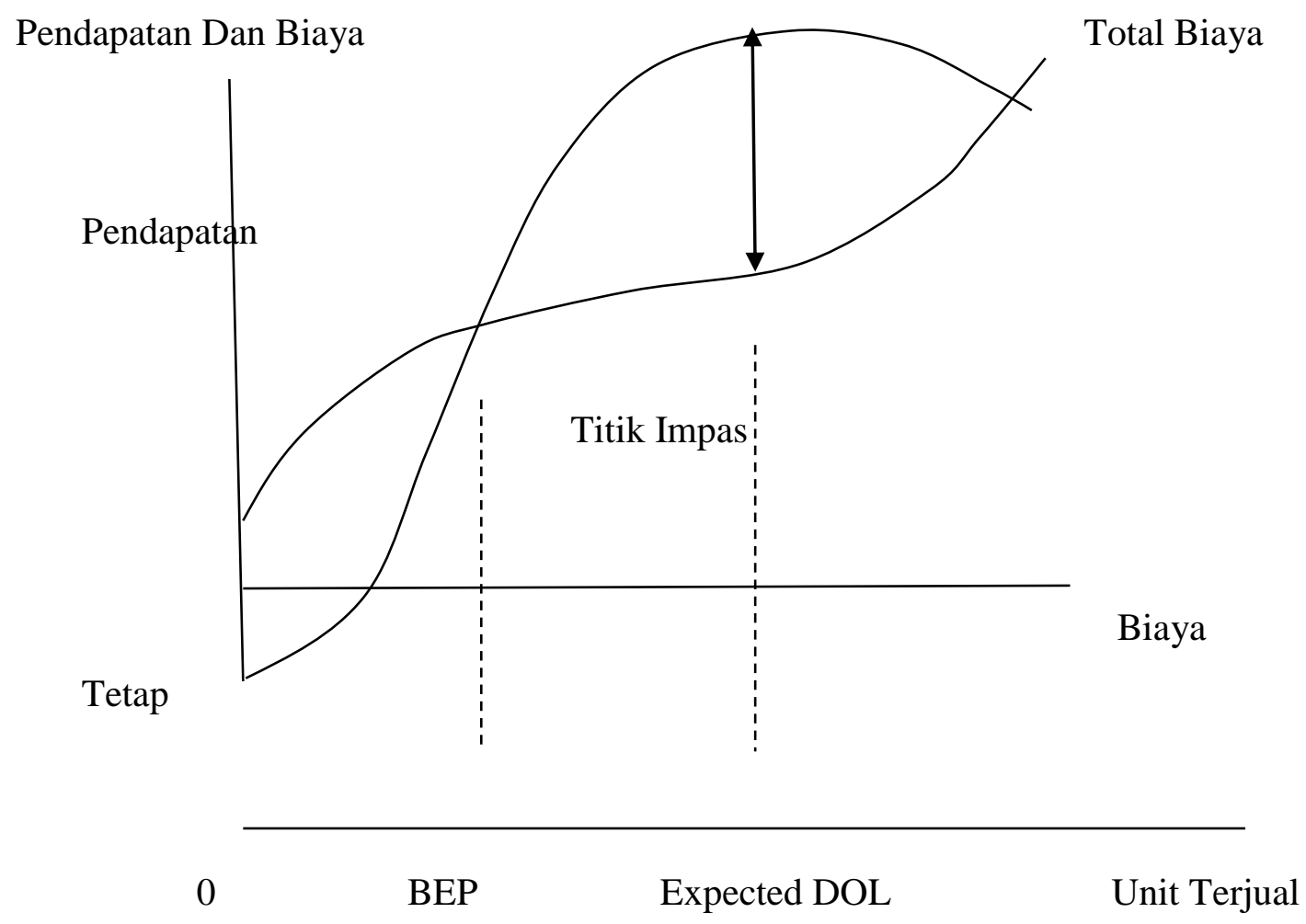

\section{Operating Leverage}

Operating leverage, Diartikan sebagai sejauh mana biaya tetap digunakan dalam operasi, tingginya biaya tetap akibat pemakaian modal yang jumlahnya lebih besar , memungkinkan perusahaan bekerja dengan tenaga kerja yang sedikit dan biaya veriabel yang lebih kecil. 
Derajat operating leverage (OL) diartikan sebagai prosentase perubahan pendapatan usaha akibat prosentase perubahan unit yang terjual.

$$
\mathrm{OL}=\frac{\text { Prosentase Perubahan Pendapatan Usaha }}{\text { Prosentase Perubahan Penjualan }}
$$

\section{Peranan Operating Leverage}

Operating leverage mempunyai peranan sebagai berikut :

1. Pengaruh relatif biaya tetap dalam operasi dipengaruhi oleh perubahan harga, perubahan biaya variabel dan perubahan relatif biaya tetap.

2. Semakin tinggi derajat operating leverage maka semakin tinggi pengaruh prosentase perubahan output terhadap perubahan laba.

3. Derajat operating leverage mempengaruhi keputusan tentang jumlah financial leverage dan operating leverage yang digunakan oleh, karena secara bersama operating leverage da financial leverage mempengaruhi variabilitas penghasilan perusahaan

\section{Perusahaan Pemimpin Pasar}

Tindakan perusahaan yang mempunyai daya gebrak tinggi, adalah perusahaan yang dapat memimpin pasar, daya gebrak tinggi tersebut dipengaruhi oleh model pendekatan strategi serta dasar pemikiran yang tepat, adapun pendekatan strategi tersebut meliputi :

1. Pendekatan inside-out, dimana pendekatan ini berfokus pada diri sendiri terlebih dahulu, dalam arti bahwa perusahaan membuat produk terlebih dahulu tanpa melalui uji analisis kebutuhan pihak eksternal yaitu konsumen dan kondisi persaingan (dinamika kompetisi). Pendekatan ini dapat diterapkan untuk kondisi yang sepi persaingan, tetapi untuk kondisi diera pasar global seperti sekarang, pendekatan ini sangat tidak tepat.

2. Pendekatan outside-in, dimana kondisi saat sekarang (pasar Global). Yang ditandai dengan munculnya kompetitor dari segala penjuru dan pertumbuhan ekonomi sering mengalami kontraksi, untuk menghasilkan pertumbuhan bisnis diatas ratarata maka model pendekatan terdahulu sangat berisiko, lebih tepat menerapkan pendekatan outside-in. pendekatan ini menganjurkan untuk melihat perkembangan diluar perusahaan, kemudian perusahaan berusaha menyesuaikan diri untuk 
melahirkan sesuatu (produk), hal ini dilakukan agar perusahaan dapat berkompetisi dengan lebih baik.

Untuk menciptakan ide (inspirasi) yang berhubungan dengan strategi bisnis yang tepat, terdapat tiga sumber, antara lain :

1. Sumber ide atau inspirasi yang berasal dari konsumen maupun non konsumen, dari pendekatan ini diharapkan dapat mengetahui keinginan konsumen yang ada yang sudah dipenuhi oleh kompetitor dan perusahaan sendiri, serta keinginan konsumen yang mana yang belum terpenuhi, antara lain apa yang menjadi kebutuhan konsumen saat ini, apa yang menjadi ekspektasi dan keinginan baru, yang kemungkinan menjadi keinginan yang akan datang, yang jelas didalam diri konsumen terdapat kebutuhan, keinginan dan ekspektasi, terlepas apakah keinginan dan ekspektasi sudah mulai muncul nyata dann segera akan menjadi tuntutan konsumen, tetapi yang jelas untuk mengetahui ini semua perlu proses penggalian dengan baik dan hal yang perlu diingat adalah dibalik kebutuhan dan keinginan ataupun harapan konsumen terdapat perspektif masalah, sehingga perusahaan harus memiliki kepandaian tersendiri dalam mendalami masalah yang saat ini dialami konsumen atau masalah masa depan yang dihadapi konsumen diharapkan perusahaan harus bisa memberi solusi jangka pendek dan jangka panjang.

2. Sumber ide atau inspirasi yang berasal dari pemasok dan pesaing, baik pesaing langsung tidak langsung atau non kompetitor yakni pemain bisnis diluar industry yang digeluti sekarang. Sering pemasok menawarkan gagasan produk atau servis dalam bentuk apapun yang baru yang bisa menjadi trend dimasa depan, sehingga bisa meningkatkan kecepatan perusahaan dalam mengasilkan nilai tambah bagi konsumen. Hal ini dilakukan dengan cara mengevaluasi seluruh pemasok mulai pemasok besar sampai kecil, dari jenis apapun yang mereka pasok selama ini, kajilah apakah mereka mampu memberikan kontribusi gagasan, produk atau layanan dalam bentuk apapun yang baru. Sedangkan untuk kompetitor langsung maupun tidak langsung, lakukan aktivitas intelijen kompetitif secara berkala agar mempu mengukur posisi perusahaan sekaligus mendorong perusahaan mencari keunggulan kompetitif terbarukan. 
3. Sumber ide atau inspirasi yang berasal dari diri sendiri atau perusahaan sendiri, idealnya posisi apapun dari organisasi perusahaan sendiri diperbolehkan menyampaikan ide, asal idenya segar dan baru, yang belum pernah diterapkan. Agar organisasi intern aktif menghasilkan ide segar, evaluasilah budaya internal yang berkembang diperusahaan, apakah budaya yang berkembang tidak mendorong terjadinya aliran ide yang bebas ataukah ide hanya boleh berkembang dikelompok tertentu, apakah organisasi perusahaan resisten terhadap kritikan atau pandangan yang berbeda, apakah budaya yang berkembang budaya paternalistic, dominan bernuansa politik kelompok, apakah organisasi cepat puas diri, puas diri yang berlebihan, apakah organisasi memiliki pendekatan dominan top-down yang menghambat kemampuan melakukan analisis secara objektif atas situasi yang ada?

Jika perusahaan terbiasa dan terjebak dalam kondisi budaya yang berkembang tidak mendorong terjadinya aliran ide yang bebas ataukah ide hanya boleh berkembang dikelompok tertentu, apakah organisasi perusahaan resisten terhadap kritikan atau pandangan yang berbeda, apakah budaya yang berkembang budaya paternalistic, dominan bernuansa politik kelompok, apakah organisasi cepat puas diri, puas diri yang berlebihan, maka perusahaan ini dapat diibaratkan seperti katak dalam tempurung, hidup tetapi tidak bermakna, dan mulai mengembangkan sistem penyaluran ide internal yang lebih terbuka.

Dengan menggunakan pola segitiga (gambar 1) dapat digambarkan dua tipe utilisasi atas ketiga sumber ide ataupun inspirasi diatas, yang dapat mengindikasikan apakah organisasi perusahaan menggunakan pola pendekatan inside-in atau outside-in .

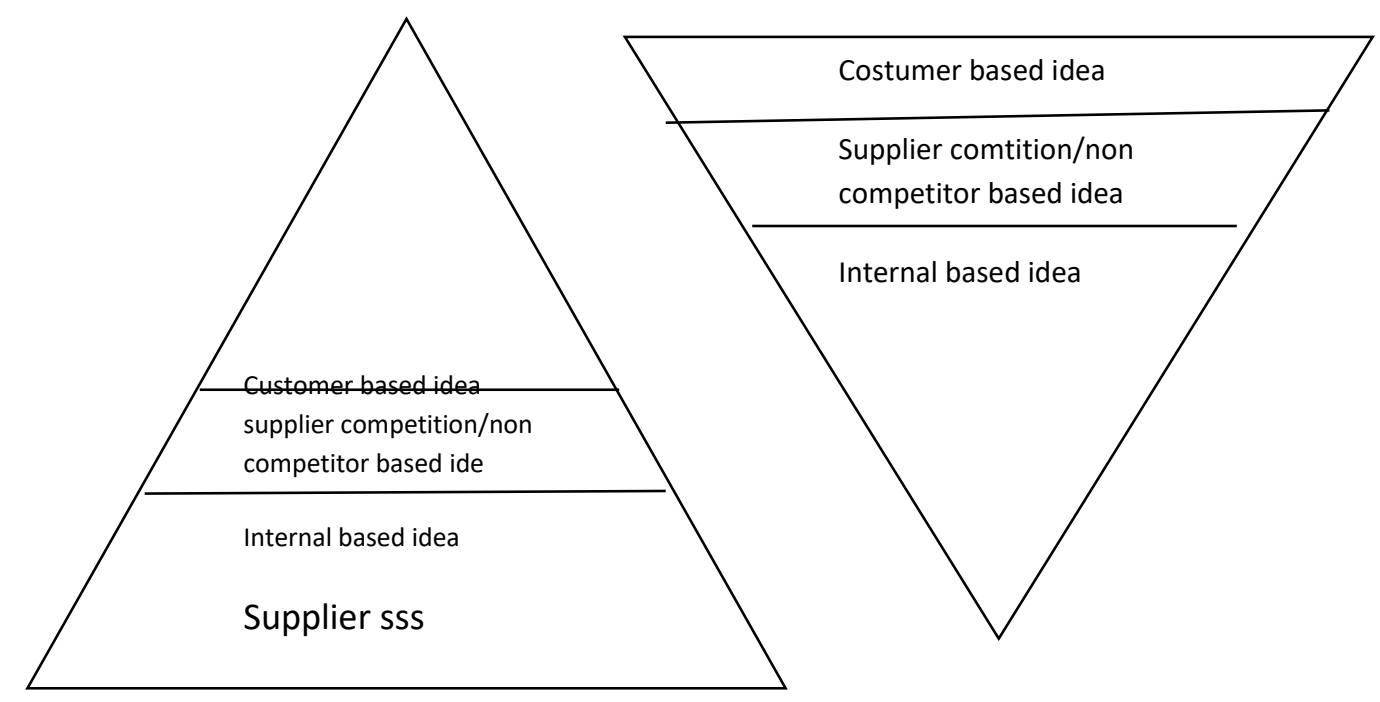


Gambar 1 : A : Pola inside-out

B : Pola outside-in

Gambar A mengidikasikan bahwa sumber ide didominasi berasal dari internal organisasi perusahaan, kemudian diikuti oleh pemasok pesaing sedangkan konsumen mendapat nomor urut terakhir.

Gambar B, mengidikasikan bahwa sumber ide didominasi berasal dari konsumen, kemudian diikuti pemasok pesaing, sedangkan nomor terakhir adalah internal organisasi perusahaan. Pada umumnya pemilihan Pola pendekatan ini dipengaruhi oleh kondisi perusahaan, dimana pada saat kondisi perusahaan stabil maka perusahaan memilih pendekatan A (inside-out), tetapi pada saat kondisi krisis dan ingin mengembalikan kinerjanya, maka perusahaan harus segera merubah pola pendekatannya dari A (inside-out) menjadi pola pendekatan B (outside-in), seperti yang dilakukan oleh perusahaan IBM pada masa krisisnya ditahun 1980-1990, yang menjadi masalah adalah apakah permasalahan ini cepat diatasi ataukah mengalami kesulitan dan tidak kunjung selesai permasalahan tersebut, maka sebaiknya sejak awal sebaikknya organisasi perusahaan selalu berorientasi pada eksternal perusahaan yaitu konsumen dan pemasok pesaing atau menggunakan pola pendekatan B yaitu outside-in, karena jika tetap mempertahankan pola pendekatan insideout, maka budaya organisasi tidak mendukung, kurang tanggap, arogansi dan tidak mempertimbangkan aspek perubahan pasar sebagai kelangsungan hidup bisnis atau perusahaan, yang pada akhirnya konsumen akan mencari alternatif produk lain dan perusahaan akan kehilangan pangsa pasar.

\section{Pemikiran Mahaguru manajemen Modern}

Beberapa pemikiran Mahaguru Manajemen modern adalah sebagai berikut :

1. Strategi bisnis yang dikemukakan oleh mahaguru Drucker, antara lain satu tujuan valid bagi eksistensi bisnis, yaitu menciptakan konsumen, yang dimaksud adalah perusahaan bukan hanya melayani dan mempertahankan konsumen, melainkan harus dapat menciptakan konsumen, perusahaan tidak boleh mengandalkan keberhasilan masa lalunya, agar perusahaan sukses dipasar. Pendekatan yang harus dilakukan adalah Market Driving, dimana dalam pendekatan ini perusahaan harus mampu secara aktif mempengaruhi struktur dan perilaku pasar, agar dapat mempengaruhi struktur dan perilaku pasar maka perusahaan harus menggunakan 
kekuatan inovatif antara lain inovatif dibidang produk, sistem transaksi, sistem distribusi, sistem pemasaran dan aspek operasional lain yang dapat mempengaruhi perilaku konsumen, untuk itu konsumen membutuhkan nilai tambah dan bagaimana perusahaan menciptakan nilai tambah terus-menerus bagi konsumen, atau jika tidak terpenuhi nilai tambah tersebut, konsumen akan meninggalkan produk perusahaan, perusahaan juga harus memperhatikan sinyal-sinyal konsumen antara lain adalah perkembangan dinamika struktur demografi konsumen, agar tidak salah membaca sinyal konsumen, dan yang lebih penting adalah bahwa keberhasilan masalalu merupakan pengalaman yang harus dikembangkan bukan sebagai sandaran.

2. Industri sebagai suatu sistem, yang dikemukakan oleh Deming, perbaikan performansi bisnis modern harus mencakup keseluruhan sistem industry mulai dari kedatangan material sampai distribusi produk ketangan konsumen serta desain ulang produk (barang dan atau jasa) untuk masa mendatang. Sistem industry yang dikemukakan oleh Deming, selanjutnya dikembangkan dan terkenal dengan "Roda Deming”, dimana dalam Roda Deming terdapat empat komponen utama yaitu Riset Pasar, Desain Produk, Proses produksi dan Pemasaran, lebih jauh Deming menjelaskan bahwa agar perusahaan dapat menghasilkan produk dengan harga bersaing, biaya efisien serta kualitas memadai sehngga dapat memuaskan konsumen, maka Roda Deming harus berjalan berdasar pengertian dan tanggung jawab bersama, untuk mengutamakan efisiensi industry dan peningkatan kualitas. Jika Roda Deming berjalan terus-menerus maka perusahaan industry modern dapat memenangkan persaingan yang sangat kommpetitif dan memperoleh keuntungan yang dapat dipergunakan untuk perluasan (ekspansi) serta kesejahteraan karyawan. Selanjutnya informasi tentang keinginan konsumen (pasar) yang diperoleh dari Riset Pasar yang komprehensif, selanjutnya didesain produk yang sesuai dengan keinginan pasar, desain produk menetapkan model dan spesifikasi yang harus diikuti oleh bagian produksi, bagian produksi harus meningkatkan efisiensi dari proses dan kualitas produk, agar menghasilkan produk berkualitas sesuai keinginan pasar dengan biaya yang efisien, maka pemborosan (waste) yang terjadi dalam proses produksi harus dihilangkan, selanjutnya produk yang berkualitas dengan biaya efisien itu didistribusikan melalui bagian pemasaran dengan harga 
yang kompetitif dalam konsep industri modern, maka bagian pemasaran bertanggung jawab langsung kepada konsumen, karena bagian pemasaran berhadapan langsung dengan konsumen, semua bagian dalam industri modern harus mendukung bagian pemasaran dalam meningkatkan kualitas, demikian Roda Deming ini harus berjalan terus sepanjang waktu secara kontinyu.

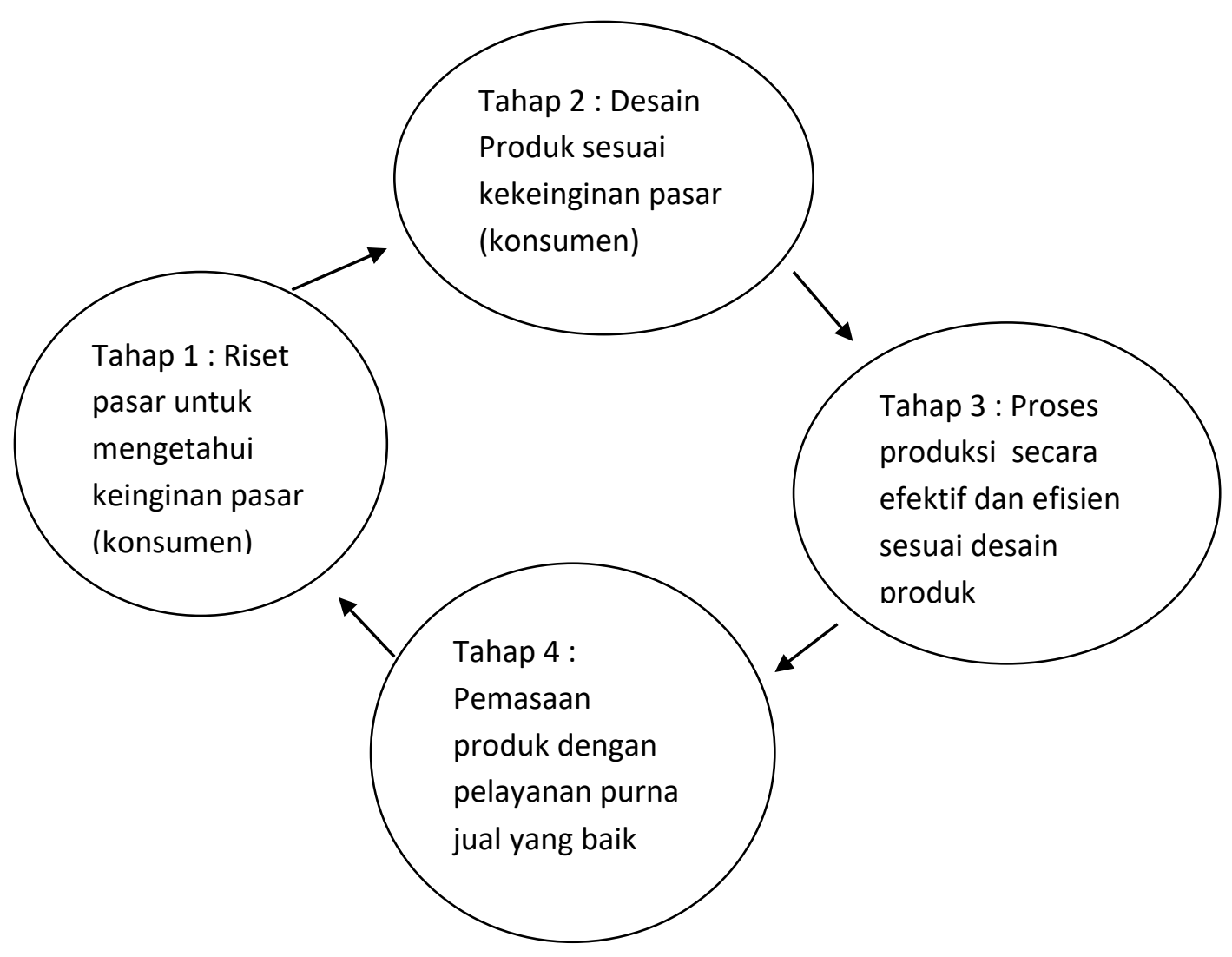

Gambar 2. Roda Deming

\section{Lima Aspek Penting Dalam implementasi Market Driving}

Terdapat lima aspek selain kedalaman inovasi dan kecepatan inovasi, yaitu antara lain :

1. kemampuan menampung, mendengar dan mengelola suara konsumen baik suara positif maupun negatif

2. kesabaran, konsistensi dan kemampuan melakukan edukasi pada konsumen yang masih belum memahami penawaran perusahaan, 
3. intensitas, kualitas, dan keragaman komunikasi dua arah yang terjadi antara perusahaan dan konsumen

4. kemampuan mengekspresikan diri sebagai bentuk partisipasi dalam membantu pemecahan masalah sosial yang ada atau dengan kata lain adakah kepedulian nyata yang terlihat dan pemilik merk untuk berpartisipasi dalam membantu memecahkan masalah sosial yang ada

5. kemampuan memberikan ruang bagi konsumen untuk terlibat dan berkontribusi dalam kegiatan ataupun aktivitas yang sedang dilakukan pemilik merk ( $\mathrm{Co}$ creation dan Co-promotion secara terbatas)

Kelima aspek tersebut harus dikemas dengan semangat bahwa :

1. Apa yang diberikan kepada konsumen selau bisa melampaui apa yang diekspektasikan konsumen sehingga tercipta aura antusiasme yang luar biasa yang terjadi pada konsumen

2. Kemasan aspek penting tersebut harus dijiwai semua aktivitas perusahaan dalam mengakuisisi, meretensi, dan mengembalikan konsumen yang hilang akibat kekecewaan yang pernah dialami saat bersama perusahaan dimasa sebelumnya.

\section{Pentingnya Manajemen Biaya}

Manajemen biaya mempunyai fungsi penting sebagai berikut :

1. Manajemen biaya merupakan sistem yang didesain untuk menyediakan informasi baik bersifat keuangan (pendapatan dan biaya) juga non keuangan seperti kualitas dan produktivitas bagi manajemen untuk

2. Identifikasi peluang penyempurnaan, perencanaan strategik dan pembuatan keputusan operasional mengenai

3. Pengadaan dan penggun sumber yang diperlukan organisasi

4. Merupakanp sistem terintegrasi yang menunjukkan adanya hubungan dengan sistem yang lain seperti sistem desain dan pengembangan,sistem pembelian dan produksi , sistem pelayanan konsumen serta sistem pemasaran dan distribusi

5. Manajemen biaya sangat penting bagi organisasi, karena bukan sekedar pengukuran dan pelaporan kos produk dan jasa, tetapi mencakup

6. filosofi, sikap dan serangkaian teknik untuk memberikan nilai tambah organisasi melalaui 
7. Teknik manajemen kontemporer

8. Informasi manajemen biaya, meliputi semua informasi yang diperlukan manajemen untuk mencapai tujuan organisasi melalui pengelolaan biaya secara proaktif

\section{Pengguna Informasi Manajemen Biaya}

1. Para manajer yang mengelola perusahaan agar menjadi lebih kompetitif dan sukses

2. Masing fungsi utama manajemen, seperti manajemen strategik, perencanaan dan pembuatan keputusan, pengendalian manajemen, pengendalian operasional dan penyajian laporan keuangan

3. Manajemen strategik, sebagai dasar manajemen untuk membuat keputusan strategik yang tepat

4. Berkaitan dengan pemilihan produk, metode pemanufakturan serta teknik dan saluran pemasaran.

\section{METODOLOGI PENELITIAN}

\section{Variable Penelitian}

1. Pasar modal, yaitu sarana yang mempertemukan peminta dan penawar dana jangka panjang dalam bentuk efek atau saham.

2. Leverage adalah merupakan beban tetap yang ditanggung perusahaan sebagai akibat penggunaan hutang

3. Break event point, yaitu alat atau teknik yang digunakan oleh para analisis untuk mengetahui tingkat volume penjualan, yang memberikan tingkat keuntungan atau kerugian sama dengan nol.

\section{Prosedur Pengambilan dan Pengumpulan Data}

Untuk pengumpulan data yang diperlukan dalam penelitian, peneliti menggunakan jenis metode pengumpulan data, yakni melalui metode pengumpulan data library reserach. Library research, yaitu merupakan metode pengumpulan data yang diperoleh dengan cara penelitian kepustakan, yaitu diperoleh melalui buku-buku pustaka sebagai bahan kajian untuk membahas permasalahan yang diteliti.

\section{Definisi Variabel Penelitian}


1. Tingkat Leverage Operasi , dapat dihitung sebagai berikut Brigham, 2010:269), Tingkat Leverage Operasi $=($ Perubahan Persentase laba operasi/Perubahan persentase unit yang terjual atau total pendapatan)

2. Laba Operasi Bersih (Brigham, 2010:269), dapat dihitung sebagai berikut,

Laba Operasi Bersih = Pendaatan - Total Variabel Cost - Total FixedCost

\section{HASIL DAN PEMBAHASAN}

Adapun pertumbuhan laba, pertumbuhan output serta degree operating leverage perusahaan manufaktur sektor aneka industri tahun 2012 sampai dengan tahun 2016, seperti nampak pada tabel 1 sampai dengan tabel 3.

Tabel 1. Pertumbuhan Laba Operasi Perusahaan Manufaktur Sektor Aneka Industri Tahun 2012-2016

\begin{tabular}{|l|r|r|r|r|r|}
\hline & \multicolumn{1}{|c|}{$\mathbf{2 0 1 3}$} & \multicolumn{1}{c|}{$\mathbf{2 0 1 4}$} & \multicolumn{1}{c|}{$\mathbf{2 0 1 5}$} & \multicolumn{1}{c|}{$\mathbf{2 0 1 6}$} & Rata-rata \\
\hline PT Sbata & 0,13 & 0,04 & 0,24 & $-0,10$ & 0,08 \\
\hline PT JCC, & 0,12 & 0,50 & $-0,16$ & 0,10 & 0,14 \\
\hline PT KM, & 0,36 & $-0,03$ & $-0,16$ & 0,25 & 0,11 \\
\hline PT KMI C, & 0,64 & 0,01 & $-0,24$ & 0,36 & 0,19 \\
\hline PT SCM & 0,24 & $-0,16$ & 0,22 & 0,02 & 0,08 \\
\hline PT Astra O & 0,10 & 0,26 & 0,91 & $-0,47$ & 0,20 \\
\hline PT Indo S, & 0,08 & 0,11 & $-0,02$ & $-0,42$ & $-0,06$ \\
\hline PT Nipress, & 0,33 & 0,29 & 0,18 & 0,01 & 0,20 \\
\hline PT Prima AS & 0,05 & 0,20 & 0,33 & 0,10 & 0,17 \\
\hline PT Astra I & 0,10 & 0,26 & 0,91 & $-0,47$ & 0,2 \\
\hline PT SS,tbk & 0,19 & 0,17 & 0,23 & 0,11 & 0,18 \\
\hline PT IRS,tbk & 0,20 & 0,29 & 0,18 & $-0,18$ & 0,12 \\
\hline PT NIC,tbk & 0,21 & 0,65 & 0,12 & 0,01 & 0,25 \\
\hline
\end{tabular}

Sumber : BEI (diolah)

Pertumbuhan laba Perusahaan Manufaktur Sektor Aneka Industri secara keseluruhan dari 13 perusahaan umumnya setiap tahun berfluktuasi dan mempunyai kecenderungan menurun, hal ini disebabkan karena kondisi perekonomian dunia masih terkena imbas resesi ekonomi termasuk di Indonesia. Pertumbuhan laba secara rata-rata dari tahun 2012-2016 dari ketiga belas Perusahaan Manufaktur Sektor Aneka Industri yang mempunyai pertumbuhan tertinggi adalah PI Nusantara IC Tbk sebesar 0,24, kemudian disusul PT Astra Tbk, PT Nipres Tbk keduanya sama yaitu sebesar 0,20, kemudian diikuti PT Kebelindo Tbk sebesar 0,19 kemudian disusul PT Prima Tbk dan PT Selamat Sempurna Tbk keduanya sebesar 0,17, berikutnya yang mempunyai pertumbuhan laba dibawah 0,17 adalah PT Jembo Cable C Tbk sebesar 0,14 disusul PT Indorama S Tbk 
sebesar 0,12, sedangkan dibawahnya PT Kabelindo Murni Tbk sebesar 0,10, kemudian PT Supreme Cable Tbk sebesar 0,08 , PT Sepatu Bata sebesar 0,07, sedangkan PT Indospring Tbk mempunyai pertumbuhan laba negatif yaitu sebesar $-0,06$

Tabel 2. Pertumbuhan Output Perusahaan Manufaktur Sektor Aneka Industri

Tahun 2012-2016

\begin{tabular}{|l|r|r|r|r|r|}
\hline & \multicolumn{1}{|c|}{$\mathbf{2 0 1 3}$} & \multicolumn{1}{c|}{$\mathbf{2 0 1 4}$} & \multicolumn{1}{c|}{$\mathbf{2 0 1 5}$} & \multicolumn{1}{c|}{$\mathbf{2 0 1 6}$} & Rata-rata \\
\hline PT S Bata & 0,01 & 0,02 & 0,11 & 0,02 & 0,04 \\
\hline PT JCC, & $-0,03$ & 0,21 & 0,02 & 0,12 & 0,08 \\
\hline PT KM, & 0,18 & 0,01 & $-0,10$ & 0,05 & 0,04 \\
\hline PT KMI C, & 0,23 & 0,13 & $-0,07$ & 0,12 & 0,10 \\
\hline PT SCM & 0,06 & 0,06 & $-0,01$ & $-0,05$ & 0,02 \\
\hline PT Astra O & 0,12 & 0,29 & 0,15 & $-0,04$ & 0,13 \\
\hline PT Indo S, & 0,20 & 0,15 & 0,10 & $-0,11$ & 0,09 \\
\hline PT Nipress, & 0,21 & 0,30 & 0,12 & $-0,03$ & 0,15 \\
\hline PT Prima AS & $-0,06$ & 0,02 & 0,41 & 0,05 & 0,10 \\
\hline PT Astra I & 0,15 & 0,03 & 0,04 & $-0,08$ & 0,04 \\
\hline PT SS,tbk & 0,20 & 0,10 & 0,10 & 0,06 & 0,12 \\
\hline PT IRS,tbk & 0,27 & $-0,04$ & 0,02 & $-0,04$ & 0,05 \\
\hline PT NIC,tbk & $-0,14$ & 0,15 & 0,005 & 0,15 & 0,041 \\
\hline
\end{tabular}

Sumber : BEI ( diolah)

Tabel 3. Degree Operating Leverage Perusahaan Manufaktur Sektor Aneka Industri Tahun 2012-2016

\begin{tabular}{|l|r|r|r|r|r|}
\hline & \multicolumn{1}{|c|}{$\mathbf{2 0 1 3}$} & \multicolumn{1}{|c|}{$\mathbf{2 0 1 4}$} & \multicolumn{1}{c|}{$\mathbf{2 0 1 5}$} & \multicolumn{1}{c|}{$\mathbf{2 0 1 6}$} & Rata-rata \\
\hline PT S Bata & 13,43 & 1,79 & 2,19 & $-4,86$ & 3,14 \\
\hline PT JCC, & -4 & 2,38 & -8 & 0,83 & $-2,20$ \\
\hline PT KM, & 2 & -3 & 1,60 & 5 & 1,40 \\
\hline PT KMI C, & 2,78 & 0,08 & 3,43 & 3 & 2,32 \\
\hline PT SCM & 4 & $-2,67$ & -22 & $-0,40$ & $-5,27$ \\
\hline PT Astra O & 0,83 & 0,90 & 6,07 & 11,75 & 4,89 \\
\hline PT Indo S, & 0,40 & 0,73 & $-0,20$ & 3,82 & 1,19 \\
\hline PT Nipress, & 1,57 & 0,97 & 1,50 & $-0,33$ & 0,93 \\
\hline PT Prima AS & $-0,83$ & 10 & 0,80 & 2 & 2,99 \\
\hline PT Astra I & 0,83 & 0,90 & 6,06 & 11,75 & 4,89 \\
\hline PT SS,tbk & 0,95 & 1,70 & 2,30 & 1,83 & 1,70 \\
\hline PT IRS,tbk & 0,74 & $-7,25$ & 9 & -9 & $-1,63$ \\
\hline PT NIC,tbk & $-1,50$ & 4,33 & 24 & 0,05 & 6,72 \\
\hline
\end{tabular}

Sumber : BEI (diolah)

Pertumbuhan output Perusahaan Manufaktur Sektor Aneka Industri dari tahun 2012-2016 secara umum berfluktuasi, namun ada beberapa perusahaan yang mempunyai pertumbuhan output berfluktuasi namun mempnyai kecenderungan meningkat seperti PT 
Nusantara IC Tbl dan PT jembo Cable C Tbk, namun selama lima tahun secara rata-rata PT Nipres mempunyai pertumbuhan output tertinggi yaitu sebesar 0,15 , kemudian disusul PT Astra Tbk sebesar 0,13, kemudian PT Selamat Sempurna Tbk, sebesar 0,11 dan diikuti PT KMI WC Tbk sebesar 0,10, pertumbuhan output yang tinggi, akan mengindikasikan bahwa dalam operasionalnya perusahaan efisien.

Degree operating leverage dikatakan menguntungkan bagi Perusahaan Manufaktur Sektor Aneka Industri, jika pertumbuhan laba operasinya lebih besar dari pertumbuhan output, dari ketiga belas Perusahaan Manufaktur Sektor Aneka Industri di Indonesia dari tahun 2012-2016 mempunyai degree operating leverage yang berfluktuasi, namun ada beberapa perusahaan yang mempunyai kecenderungan meningkat, secara ratarata degree operating leverage Perusahaan Manufaktur Sektor Aneka Industri di Indonesia selama lima tahun yang tertinggi adalah PT Nusantara Inti corporate Tbk yaitu sebesar 6,7, kemudian disusul PT Astra Outopart Tbk dan PT Astra Internasional Tbk sama sebesar 4,8 kemudian dibawahnya PT Sepatu Bata sebesar 3,1 dan PT Prima Aloy Steel sebesar 2,9, sedangkan PT KMI WC Tbk sebesar 2,3 disusul PT Selamat Sempurna sebesar 1,6 kemudian dibawahnya yaitu PT Kabelindo Murni Tbk sebesar 1,4, PT Indospring sebesar 1,18, PT Nipres Tbl sebesar 0,9, sedangkan PT Jembo CC Tbk, PT Supreme CM Tbk dan PT Indorama Syntethetic mempunyai degree operating leverage yang negatif. Semakin kecil derajad degree operating leverage menunjukkan bahwa dalam operasionalnya suatu perusahaan semakin tidak efisien, karena besarnya pertumbuhan output tidak diikuti pertumbuhan laba operasi yang semakin besar.

\section{KESIMPULAN DAN SARAN}

\section{Kesimpulan}

1. Dari ketiga belas Perusahaan Manufaktur Sektor Aneka Industri di Indonesia dari tahun 2012-2016, yang mempunyai degree operating leverage tertinggi adalah PT Nusantara Inti Corporate Tbk sebesar 6,7 kemudian diikuti PT Astra Otoparts Tbk dan PT Astra Internasional Tbk yaitu sama sebesar 4,8

2. Dapat dikatakan bahwa ketiga Perusahaan Manufaktur Sektor Aneka Industri di Indonesia tersebut, dari tahun 2012-2016 lebih efisien dibandingkan dengan perusahaan yang lain didalam industri Perusahaan Manufaktur Sektor Aneka Industri, 
3. Dapat dikatakan bahwa ketiga Perusahaan Manufaktur Sektor Aneka Industri di Indonesia tersebut, dari tahun 2012-2016 lebih efisien, dalam arti bahwa kenaikan dalam biaya tetap dapat menurunkan biaya variabel yang lebih besar.

\section{Saran.}

1. PT Nusantara Inti Corporate Tbk, PT Astra Otoparts Tbk dan PT Astra Internasional Tbk dapat mempertahankan bahkan meningkatkan degree operating leverage.

2. Perusahaan lain dalam indstri Perusahaan Manufaktur Sektor Aneka Industri di Indonesia, dapat meningkatkan degree operating leverage.

\section{DAFTAR PUSTAKA}

Alwi, Syafarudin. 1991. Alat-Alat Analisa Dalam Pembelanjaan. Edisi Revisi. Yogyakarta : Andi Offset

Baritwan. 1997. Alat Analisa Keuangan. Edisi Keenam. Yogyakarta : Penerbit BPFE.

Brigham, Eugene F. and J.F. Weston. 2001. Manajemen Keuangan. Edisi 8, Jakarta : Erlangga.

Copeland, Thomas E. 2001. Manajemen Keuangan, Edisi 8. Jakarta : Erlangga.

Husnan, Suad. 1993, Pembelanjaan Perusahaan (Dasar-Dasar Manajemen Keuangan), Yogyakarta : Liberty

Mamduh. 1996. Analisa Laporan Keuangan. Edisi Keempat, Yogyakarta: Penerbit BPFE

Riyanto, Bambang. 2001. Dasar-Dasar Pembelanjaan Perusahaan, Edisi Keempat, Yogyakarta : BPFE.

Sartono, Agus. 2001, Manajemen Keuangan, Edisi Keempat. Yogyakarta : BPFE. 